\title{
COUTO, ELZA K. N. N. ECOLINGUÍSTICA E IMAGINÁRIO. BRASÍLIA: THESAURUS, 2012.
}

\author{
Resenhado por Genis Frederico Schmaltz Neto ${ }^{1}$ \\ (Universidade Federal de Goiás)
}

Elza K. N. N. do Couto possui mestrado e doutorado pela Pontifícia Universidade Católica de São Paulo e concluiu recentemente seus estudos de pós-doutorado pela Universidade de Brasília sob a orientação de Hildo Honório do Couto - mentor cujos postulados a levaram da rua para o meio ecossistêmico. Isso porque em seu último livro "Em busca da casa perdida: vozes e imaginário de meninos de rua" (Annablume 2005), a professora da Universidade Federal de Goiás enfrentara o desafio de unir a teoria do imaginário de Gilbert Durand à semiótica greimasiana para compreender o ambiente imagético que circunda os meninos de rua. Agora, em sua nova publicação, seu feito é ainda mais ambicioso: unir os escritos de Durand à Ecolinguística.

Dividido em onze capítulos que se agrupam entre asserções do Imaginário e da Escola Ecolinguística de Brasília, o livro tem a premissa fundamental de que "para associarmos [as teorias] é necessário fazêlo via ecossistema mental da língua, que é apenas um entre os três outros, o natural e o social" (p. 13). Sutilmente a autora demonstra que desde Platão, passando por Wittgenstein, Sapir, Haugen e Matos, há a necessidade de uma reflexão efetiva que situe a língua para além de suas estruturas internas ou condições de produção, e, portanto, a Ecolinguística emerge como caminho para que a língua e a linguagem sejam compreendidas por meio de seus ecossistemas, por meio da interação que têm com o ambiente.

Esse "ambiente" não se limita às terminologias biológicas ou a uma abordagem moralista do "verde" que circunda o povo

1. Mestre em Linguística pela Universidade Federal de Goiás e pesquisador do Núcleo de Estudos Ecolinguísticos e Imaginário - Nelim/UFG. 
que fala uma língua, o território de onde se fala e as comunidades de língua e comunidades de fala. Antes, a biologia e seus conceitos fundamentais servirão de base epistemológica para que a linguística se expanda e o prefixo -eco origine e adicione a diversos estudos a perspectiva de inter-relação, a compreensão de que a língua é parte de um ecossistema. Encontramos assim estudos como 'etnoecologia linguística', 'linguística ecossistêmica', 'ecossemiótica', 'ecolinguística dialética', 'ecologia da aquisição de língua', 'ecologia da evolução linguística' e a lista se estende.

Couto se questiona e nos faz compreender por que o caminho ambiental deve ser trilhado se as tantas reflexões suscitadas das diversas possibilidades de pesquisa ecológica parecem poder ser pensadas por meio de outras teorias como a sociolinguística ou mesmo "como o discurso é construído, o ethos do enunciador, a ideologia, o estudo do contexto sócio-histórico” (p. 52) às semelhanças de uma análise crítica do discurso. A resposta pode soar um tanto ostensiva: "se considerarmos que a base da Ecolinguística é a ecologia, a ecologia biológica, vamos entender que ao fazer análise de um discurso cujo tema é o meio ambiente sob o viés da ecolinguística já estamos sugerindo uma diferença” (p. 53).

O olhar treinado pelo conhecimento aprofundado nos conceitos bioecológicos permitirá considerações teóricas abundantes que somam às outras disciplinas das quais solicita ajuda para complementar suas reflexões. Esse é o grande trunfo e talvez a grande problemática dessa nova ciência que está "em um patamar mais amplo, sendo não apenas interpretativa, mas crítica e interventiva [...] inter, multidisciplinar" (p 52) que parece abranger todas as demais áreas científicas e possuir o poder de contê-las. Tem-se uma expressiva gama de ferramentas metodológicas, mas também longínquas maneiras de se manuseá-las ecologicamente.

Todavia é aqui também que se encontra a brecha teórica que permite trazer a antropologia do Imaginário de Gilbert Durand não apenas como aresta complementar à teoria ecológica, mas também como alicerce: por se tratar de uma vertente holística de análises do homo sapiens que integra o biológico, o psíquico e o pulsional junto às 
intimações do meio-social, analisar o Imaginário - que é a faculdade humana de produzir, manusear, criar, distinguir, memorizar, reproduzir e articular imagens - se equipara a pensar os meios de funcionamento do 'ecossistema mental da língua'.

As três formas de análise durandiana que se pautam pela interpretação, descrição e associação simbólica de discursos e produções humanas, sejam elas feitas pelo teste projetivo AT-9, pelas modalidades de imagem ou pela análise mitodológica, podem se estender e amplificar a leitura ecológica formulando-se perguntas e investigando não apenas a língua que interage com o meio ambiente, mas as imagens que determinada língua provoca na comunidade, quais mitos subjazem a existência de seu território ou que imagens esse meio ambiente suscita em seu povo. Mais ainda, que arquétipos sustentam e concretizam a inter-relação ou que constroem determinado ecossistema.

Couto encerra seu livro evidenciando a necessidade de um diálogo mais aprofundado entre as teorias ainda que a princípio pareçam discrepantes e temporalmente afastadas, mas, sobretudo provocativas: tudo "está na mente do indivíduo [...] e nesses indivíduos cujos corpos fazem parte da natureza, se encontra o cérebro, também ele parte da natureza. É o cérebro que constitui o lócus dos processos mentais em que se inscreve o imaginário" (p. 90). Será essa uma nova luminária sobre o caminho que os ecolinguistas do imaginário devem trilhar? A necessidade de se recorrer aos pressupostos biológicos para compreender o Homem pode ser mais interessante (e urgente) do que se imagina.

Recebido: 03/01/2013

Aceito: 08/03/2013

gfschmaltz@gmail.com 